\title{
The Dilemmas of Democracy in Latin America
}

\author{
José Luis Tejeda González \\ Universidad Autonoma Metropolitana, Mexico City, Mexico \\ Email: gorgias10@hotmail.com
}

How to cite this paper: González, J. L. T. (2020). The Dilemmas of Democracy in Latin America. Open Journal of Political Science, 10, 521-545. https://doi.org/10.4236/ojps.2020.103032

Received: June 8, 2020

Accepted: July 24, 2020

Published: July 27, 2020

Copyright (c) 2020 by author(s) and Scientific Research Publishing Inc. This work is licensed under the Creative Commons Attribution International License (CC BY 4.0).

http://creativecommons.org/licenses/by/4.0/

\begin{abstract}
The democracy is finally almost universal referent in the Latin America region. New antagonisms and overflows put her to the test. The rise of the lefts in the zone encouraged hopes and new concerns for the democratic future. A sector of the ruling left acquired an authoritarian tonality which drove the re-election and militarism. Oligarchic groups reactivate the coupist expectation as a response to the growing influence of progressive alliances. Issues such as freedom of expression, the property rights, the frameworks of liberal democracy and the structuring of national states are placed in the center of disputes over the future of the zone. The progressive option has been closing and there is a recovery of central and conservative positions, bringing more pressure to the possibilities of a democracy that oscillates and it puts at risk.
\end{abstract}

\section{Keywords}

Identity, Left, Nation, Reelection, Militarism

\section{Introduction}

After the classic debates of developmentalism and dependency in Latin America, democracy and modernity occupy a relevant place in the issues to be developed in the last two decades of the last century. It would be assumed that democracy was a universal ideal to be achieved in the region and theories of political transition fully accounted for this circumstance. Along with Mediterranean and Eastern Europe, Latin America experiences one of the democratizing waves, which serve as a point of reference for thinking about the political transition and the construction of democracy itself. That wave served to dismantle authoritarian regimes and military dictatorships. Democracy seemed to settle in the region and yet new dilemmas and antagonisms lie ahead.

Its relevance and its universal and regional scope are rediscussed. In a post-transitional era, it is important for the endorsement of commitments to 
democracy. In the article is defended the universalist scope of the democratic project. It is assumed that democratic construction is based on the internal dynamics of nations and fits with the best traditions of humanity. In fact, all the ideologies and cultures of modernity project are beyond their specific reality. They take root in turn, locally and regionally. The democratic alternative passes through these universal processes and relative nationalization. Latin America appropriates democracy as one of its central references and continues to produce complex and problematic horizons that merit new reflections and updates. Social and ideological antagonisms, limits to ownership and functions of State, individual freedoms and mass communication, state sovereignty and the use of natural resources, the national State, and the challenges of indigenous multiculturalism, authoritarianism and warlordism, reelectionism and militarism remind us that democracy is a field always under construction, never a definitive solution to the problems of Latin America. Democracy is on the razor's edge of Latin American political life, it is needed and required and it seems difficult for us to renounce it.

1) Democracies in predicament

How does democracy become Latin American political referring for excellence in the latter part of the 20th century? It is given because it is an inclusive, peaceful and moderate option that lowers the level of confrontation to, which economic, political, social and cultural conflicts in the region have escalated. In sectors reluctant to it, suspicion spread that the democratic alternative was a strange imposition on the idiosyncrasy, values and customs of the Latin American nations. The favorable reference to democracy in the western sphere is growing up in the second half of the last century. Going back further to the beginning of the century, we find that democratic regimes were an exception of a few nations in the world, which is expanded to just over a dozen by including democracies called exclusivists (Therborn, 1980: p. 29). Despite its institutional and cultural weakness, democracy was an ideal of political modernity, since the American and French Revolutions, and since then tended to become universal (Sen, 2001: p. 12). The political and cultural tradition of the left, in turn, nourishes from democracy and wanted to give it an ideological and class bias with the so-called popular democracies. Those were the terms that defined the regimes of "existing real socialism". In the best sense, the western left tries to recover the line of direct and participatory democracy. Even cultural enemies of democracy like the Catholic Church progressively assumed it. The same happens with the aristocratic reminiscences that mimetize and lay the foundations for a portion of modern conservative parties. Only the fascist and Nazi extreme right maintains a permanent state of war against democratic regimes. The geopolitical outcome of World War II would give an unusual projection to the democratic aspiration.

The democratizing waves that occurred in the second half of the last century are led by the industrialized West. Hence the accusation that the universalization of democratic regimes is an inculcation of world powers towards traditional, re- 
gional, and local societies. It was said that it was part of imperialist expansion and of what would later be defined as globalization. This appreciation is wrong if it is taken to the verbatim. It cannot deny the interest of industrialized nations to extend common values that help understanding and the constitution of a world community. Still less would it be avoided that there is a hegemonic interest in undemocratized regions. Only it is an insufficient explanation, since there are internal processes that push in the direction of political and cultural modernity (Ansaldi 2001: p. 19). Latin America experiences the process of globalization of political and cultural values, with more intensity since the gestation of independent nations. Traditions and different values, even antagonistic, of localized and territorialized communities, have been contrasted with others of international and cosmopolitan scope. Even traditions deeply rooted in today's nations, such as Catholicism, have a remote and distant origin. It is not far behind the socialist or communist ideology that now is intended to be recast. So the argument of the estrangement and externality of democracy falls flat. It is impossible to maintain a society or community with purely local or territorial values. In the long run there is a tendency towards interdependence, openness and communication.

Democracy is born in Athens and what the industrialized nations have done with it turns it different from what it would be in its old version. Just as a nation experiences the assimilation and appropriation of the best of humanity with technological inventions and discoveries, and adaptation of institutions, values and social and cultural customs. Of course, these processes are slower and can even fail or deform, giving rise to singular historical phenomena, to an adulterated political formation. In reality, the argument of the externality of democratic values serves as an excuse to gloat us in the unpresentable political and cultural traditions of the region. So the existence of universal cultural, political and ideological references is inescapable. Although the great narratives and totalizing and utopian projects have fallen, we have coordinates left on which we move and act (Taylor, 1996: pp. 31-33). The democratic ideal is found in this field of inclusive, viable and achievable projections, with possibilities for continuous improvement.

Presenting the discussion in terms that democracy is not made for Latin Americans is idle. It is so to the extent that it has been the product of the maturation of internal and national processes, of respect and promotion of individual liberties, of the formation of citizenship and public opinion, of the gestation of political parties, social and sectoral organizations and of the establishment of institutions, controls and counterweights to the power and the established factual groups. In the political and constitutional imaginary, the democratic ideary is present since the 19th century and even earlier. In reality, its concretion has been more difficult, because the democratic experience is limited by other cultural traditions, power factors and political processes that limit and obstruct it. Hence, simulation or weak and fragile democracies are common in the zone. It has had to coexist, cohabit and strive with other historical and cultural traditions. Since 
the nineteenth century and with the birth of the young independent republics, it has been settled as a constitutional form and although civil rights and individual guarantees are hardly respected, universal and effective suffrage has been given and there are republican institutions and a weak democracy. Historical swings and zigzags are usual in the region and democratic groups receive a boost from internal social and popular pressure and from nations with a stronger republican and democratic institutionality. The democratic sectors face conservative, oligarchic, clerical and militaristic forces that resist and oppose historical changes. Between advances and setbacks, it is worth mentioning that the last democratic cycle that comes from the seventies, reaches the nineties and becomes lasting (Mainwaring, 1999: pp. 315-316). New antagonisms, conflicts and defiance force an update and a redefinition of the democratic referent in the current century.

So democracy comes us from remote traditions, like many other slopes of the economy, politics, culture and ideology. There is nothing strange about that. A sector of Latin American societies and towns have become carriers of this political and cultural tradition. At a time in regional history, it is accepted as a form of government and viable and recommendable political culture for Latin American reality. So much so that the legal provisions and institutional structure were shaped to these ideal requirements, equally regional and that tend to be universal. Whether in its demoliberal version or in of radical dermocracy, it manages to take root in Latin American social and political thinking in the first half of the $19^{\text {th }}$ century (Soler, 1986: pp. 33-34). In this way it becomes the most important political, cultural and institutional referent in the zone. It is identified with the most advanced and evolved in the region and in the world. It is obvious that groups, sectors and factors of undemocratic power remain hidden, regroup with a "democratic" facade and play to a certain extent with the rules of the game of political modernity. The fact that to a large extent authoritarianism is analyzed in the light of the levels of liberalization and democratization achieved shows us date it is on the defensive. In some authors recent authoritarian regimes are characterized by the use of dictatorship and repression current although they promise something else for the future (O'Donnell \& Schmitter, 1994: pp. 31-32).

International events accomplish their part in the maturation of Latin American democracy. This is the broadest dynamics of the modernity project (Habermas, 1989: pp. 28-29). Hence, democracy appears as part of an imperial strategy, which is imposing institutions, values and customs alien to national reality. It is useless to deny that such interests exist and that geopolitics comes into operation in these civilizing disputes. However, it is absurd to reduce democratic processes to this external conditioning and deny that within societies and Latin American states there are conflicts over power spaces and the democratic imaginary gains adepts among the region's elites and the social and popular sectors. To such an extent that most of the actors, subjects and social and political and forces recognize themselves in democratic systems and have 
declaredly accepted their commitment with democratic regimes and processes in the area. Democracy is viewed from different perspectives, there are different degrees of commitment to it and there are different levels of maturity in democratic processes, in political transitions and in the consolidation of political systems.

Just as there is an impulse from global powers to manage democracy in their own way, there are local and national interpretations and translations with a social and popular background. As it is given with government lefts in the subcontinent. The intensity of the political struggle overheats political systems and the different interpretations and temporalities of democratic processes put in a state of predicament the validity of the regional democracy. In an era of post-transition or post-hegemony, democracy must continue to strive for its validity. They have called it post-hegemonic to a political time, in which hegemony no longer depends centrally on the state and it expands beyond national borders (Beasley-Murray, 2010: pp. 13-14). The question here is whether democratic regimes are in a position to process the diversity, conflict and antagonism that have emerged in the area, or whether they are submit to the instrumental interests of one of the competing powers, whether they are elitist, global, social or popular.

2) A relay on the left: Cuba and Venezuela

In the United States, a left-wing alternative could never stabilize and the political system that emerged is a bipartisan model with slight variations in national leadership. Above and behind of the bipartisan system are imposed the interests of an industrial, military and technological complex, administered by a ruling upper class (Domhoff, 1987: pp. 17-19). Latin America would be considered as part of the zone of natural influence of the United State. The North American exportable model would be the bipartisan system, while the Latin American zone is beyond the shackles of a restrictive electoral political scheme. There are nations with a more pronounced tendency towards bipartisanship, others where the populist phenomenon gestates hegemonic parties and popular fronts and a last segment with a social response, which pushes towards an alternative from below. An almost constant common denominator in the area is the presence of sectors of the political, electoral and social left that make the management of restrictive democratic political systems more difficult. Where bipartisanship operated, strong pressure was received from non-integrated social and popular sectors, which showed the limitations of restrictive politics.

The Cuban Revolution at its time, in the late 1950s and early 1960s, strained the regional situation. A challenge is given to the imperial power in the region, a revolutionary model is offered that disdains the usual democratic forms and faces social issues that the rest of the region was poorly attended to and completely neglected. Latin America was debating between authoritarian regimes such as the Mexican, military dictatorships and restricted democracies that hardly served as an example for the region. They were democracies that did not have 
within their horizon the possibility that social and popular forces would gain power. The Cuban revolutionary regime is implanted at the critical point of the "Cold War", which intensifies more, when the access routes of the left in Latin America are obstructed by the United States and by the blocs of dominant forces in the area (Perez-Stable, 1998: pp. 141-143).

The seduction that the Cuban revolution had over a sector of the Latin American community did not allow an objective view of the nature of the new regime and the simple fact that it faced the empire a few miles away was more than enough to give it a letter of naturalization. The United States and almost all the governments in the area gave a reverse reading to the revolutionary process and to the dictatorship that is subsequently established. It is located as a threat to the imperial, oligarchic and dominant interests in the region and it was identified as an area of Soviet influence that reproduced the Marxist-Leninist model in which western democracy was taken as an empty shell. Instead of simply democracy, the form of a "popular democracy" is adopted, which would tend to be confused with the dictatorship of the majority and totalitarianism. The Cuban anomaly recomposes the internal and external relations of the Latin American nations. The OAS (Organization of American States) expelled Cuba from its bosom, only with the demarcation of the Mexican government, which would influence the attitude of the island regime towards the region (Heller, 2003: p. 675).

Although the Cuban regime is stabilizing and concentrating on the internal political process, it does not stop influencing and pretending to do so in the rest of the continent. These are the years of the armed route, of the Guevarista experiment and of the proliferation of guerrillas groups in most of the subcontinent. In the 1960s and 1970s it was confirmed that the only way for the left to gain power in Latin America was the armed route. American policy destabilized and overthrew governments that went beyond the parameters set by them, ratifying the revolutionary response as the only alternative way. Salvador Allende's rise to power from the democratic path to Socialism in Chile would be only a passing illusion. The fall of the government of the "Popular Unity" in Chile in 1973 and the implantation of military regimes in most of the subcontinent, closed any possibility that the democratic game would open beyond conventional political forces. The triumph of the Sandinista revolution in Nicaragua in 1979 confirms the viability of the armed struggle to defeat the dictatorships and the dominant blocs in the area. In the long run, Sandinismo had to face the political and electoral dilemma, and they decided to call democratic elections in which they would be defeated, in 1990 (Vilas, 2005: pp. 131-132). In Nicaragua, the revolutionary path had to face the democratic dilemma and the Sandinistas lost power in the 1990s, lasting 16 years as an opposition force.

In the eighties, the last armed combats of the revolutionary left occurred, moving to Central America. The wear of war imposes the path of dialogue and conciliation to establish a common background of convulsed societies and peoples (Poitevin \& Sequén-Manches, 2002: pp. 75-81). The fall of the "Berlin 
Wall" and the collapse of Communism will end up clearing the way for the democratic course in the region. The more traditionalist lefts are falling and the armed option is no longer in use. Only the episodic eruption of the EZLN ("Ejército Zapatista de Liberación Nacional") in Mexico in 1994 and the survival of the FARC ("Fuerzas Armadas Revolucionarias de Colombia"), the ELN ("Ejército de Liberación Nacional"), the EPL ("Ejército Popular de Liberación") in Colombia escape to the predominant trend in Latin American leftist politics. The EZLN has had to move on difficult terrain as it is an insurgent organization in conditions of peace. Nowadays, it is a "symbolic" guerrilla, surviving by an implicit truce with the Mexican governments. The FARC had more difficulties in obtaining social acceptance of their armed condition, since they have been linked to drug trafficking and other illegal activities (Guillermoprieto, 2000: pp. 33-35). They have also resorted to reprehensible methods such as terrorism and kidnapping against civilians. In the face of the Colombian case, the accusations of the links of sectors of the left with drug trafficking are beginning to manifest, mainly in Colombia, Venezuela and Bolivia. The FARC signed a peace agreement with the Colombian government, transformed in 2016-2017 and became a political party, leaving only the ELN and small armed groups splited from past guerrilla groups.

Meanwhile, Cuba, which offered at its time the referent of strongest revolutionary dictatorship in the region, suffers isolation at a bitter moment of international socialism. The Cuban regime was in serious difficulties when the Soviet Union collapsed, which was its main support in the economic, political and ideological aspects. There was even speculation about his survival (Oppenheimer, 1992: pp. 162-163). Cuba, along with China, North Korea and Vietnam go through the nineties, in the solitude of the ruins of socialism. The Cuban model, previously taken as a guide for revolutionary changes in the area, ceases to be so. The Cuban Revolution had taken over from the aging Mexican Revolution of 1910. No one took over from the Latin American left, until Chavismo and the victory of the continental left injected him with some extra respite. The Cuban regime, considered a regional anomaly, is no longer taken as a guide to get ahead, but as a parameter of what one does not want to repeat. On the same island, there is now debate about how to face the post-Castro era, in the face of Fidel Castro's death in 2016 and the necessary generational renewal. Although there are tendencies that point to the preservation of what exists, it is difficult to manage the past and pursue in tension over an encysted revolutionary process. Regional geopolitics aggravates the uniqueness of the Cuban case, while the left of the subcontinent takes flight in the midst of the crisis of international socialism. Although the Latin American left resents the fall of the socialist bloc, an important aspect of its identity is forged in relation to the United States, and this situation, far from improving, is updated once again.

The first attempts of regional regrouping of the Latin American left are made as soon as the communist bloc ends. To the collapse of the world left, it is accompanied it and succeeded by the Venezuelan "caracazo" in the beginning of 
1989, the riots in Los Angeles, California in 1992 and the neo-Zapatista uprising in 1994. The first leaderships of the post-communist Latin American left, acquire a democratic character as observed with "Lula", and the PT in Brazil and Mexican neo-Cardinalism. The antiglobalizing movements that bursted in the last part of the nineties and the beginning of the 21st century, are nourished from the Latin American social movements, particularly the Brazilian process and the Mexican neo-Zapatista experience. In fact, the anti-globalization movement bursts into Seattle and is organized in Porto Alegre (Seoané \& Taddei, 2001: pp. 105-107). The Cuban regime remains in reserve and hardly if it heeds an appearance in the recomposition of the regional left. It is dedicated to surviving and waiting for better times, while there is a recovery of leftist currents in the area. Since then, a series of contradictions have remained within the anti-globalization movements and the new Latin American left. The Cuban regime is an inheritance from a communist past that many do not accept as valid. It ceases to be a model to the extent that only a minority identifies with the type of regime of ancient communism, although only a few dare to request or demand changes to the Cuban regime. It introduces a radical ingredient, which pushes to extremisms. It is one of the living sources of Latin American political antagonism. There is no longer an armed struggle, but a warmongering struggle, of high confrontation. It must be remembered that radical policies tend to destroy democratic regimes (Ackerman, 2006: pp. 129-131).

The coming to power of Hugo Chávez in 1998, modifies the regional context in various senses. Chávez ascends to power in the framework of an acute crisis of the model of Venezuelan political representation, with a population led by the middle class and shaken by the effects of restrictive economic policies (Sánchez García, 2003: pp. 38-40). He is made of the initial support of middle business groups (Medina, 2001: pp. 109-110). He does not take long to confront economic power and embark on a path of radical populist nationalism that gradually brings the Venezuelan regime closer to the Cuban model. Venezuela takes over from Cuba, as the nation that confronts the empire and does so in better strategic conditions. The Chavista regime makes a tie to Cuba and helps to resolve its emergency economic situation while in Venezuela a popular social base is consolidated with which it undermines the strength of business and conservative groups. This does it with authoritarian methods and with the military as a decisive battering ram of the confrontational policy that he applies (Blanco, 2002: p. 50). This causes it an estrangement between liberal and democratic sectors, which does not accept with pleasure the strengthening of a regional authoritarian left. Social policy allows it to build a strategic popular base with which he strikes transnational sectors, business sectors, and even the middle class, who look with chagrin at Chavismo's attempts to approach the Cuban process on another scale and in other circumstances. Chávez imposes a model of access to power, of exercise of it and of regional projection that extends to other countries, until it forms a block of the Latin American left, which with Cuba and Venezuela at the forefront would encompass Nicaragua, Bolivia, Ecuador, Honduras and El 
Salvador as followers, at the beginning of the current century. The Chavista model, continued with Nicolás Maduro, is of a unipersonal, authoritarian and caudillista style, which return the social and popular claims that neoliberal policies neglect and never take into account. As we will see later, in Honduras in 2009 and Paraguay in 2012, the first breaks in this model occurred, with the most deplorable scenarios, such as would be technical, judicial and military coups in the region.

The Chavista model is close to the Cuban regime, but maintains its specificity in the conditions of the world of the 21st century. Chávez is initially a failed coupist who later resorts to democratic methods to seize power. At the beginning, he has great popular support that includes businessmen and the middle class, who take him as a way out before the crisis of political representation that the country is suffering. The economic and social redistribution policy that he promotes leads him to confront businessmen, landowners, and the Catholic Church. Later, the estrangement arises with the majority sectors of the middle class, which become one of the bulwarks of the opposition to Chavismo. By failing the attempted coup or "civilian insurgency" in the April 2002 crisis, Chavismo tends to reinforce itself. It increasingly concentrates power, setting in motion constituent processes that detract from the other formal powers of the republic. The Chavismo ends with the classical division of powers that nourishes from the liberal democratic tradition, reconcentrates the power around the figure of the strong man and gradually weakens the civil groups that oppose him, the middle class disaffects the regime and the mass media that become a crucial element of the power dispute in Latin American political processes.

In the long run, this path is reproduced with its singularities in Nicaragua, Bolivia and Ecuador mainly. The failure in the management Bush's son in his dealing with Latin America detracts American influence in the region. Never as then the subcontinent was so distant from North America and principally from the United States. This allows the flourishing of national and regional powers, which more reflect the balance of internal forces in the region. The failures of Bush Jr.'s management are combined with the disastrous economic policies of the conservative, oligarchic and neoliberal, national administrations that left the region battered. Its restrictive and unpopular character would make them pay the invoice. To the rise to power of Chávez in Venezuela, was added the arrival to the presidency of the republic in Brazil of Luis Ignacio Lula da Silva in 2003, who would be the first triumph of a democratic and progressive leftist government in the region, since the military coups of the sixties and seventies and particularly the one orchestrated against the socialist government of Salvador Allende in Chile. Lula does so with broad political alliances, but momentarily takes the left out of the marasmus (Alves, 2004: pp. 126-138). Lula's rise also coincides with the coming to power of Néstor Kirchner in Argentina, in the same year. The economic and political crisis of 2001 in Argentina, it led, after several unstable governments, in the Kirchners' seizure of power, whom came from left-wing 
Peronism. The predominant trend that is given at the beginning of the century is the victory of center-left governments, as occurs in Uruguay in 2004, Paraguay in 2008, and to a lesser extent in Chile with Michelle Bachelet in 2006. Regional geopolitics is modified in an important way, to degree as that the influence of Brazil and Venezuela becomes decisive, in two versions of what would be the lefts of the early $21^{\text {st }}$.

So is explained that the center-left governments reproduced in the area, while the Chavista model was applied in a block of 4 and up to 5 Latin American societies and governments. The presence of Chavismo in the subcontinent aggravates tensions and antagonisms and puts at the center of the discussion a series of issues that considered settled or of low relevance. There are three issues with which Chavismo overheats the restricted democracies that existed in the region. One is the package of issues linked to property, public space and national sovereignty. When introducing as a response to neoliberal projects, it therefore offers a revaluation of the public dimension and of state. It messes with territorial and capitalist property, for the sake of a distributive policy more equitable. By infringing the property rights and economic freedom, it makes civil society fragile, starting with multinational companies, private corporation, and reaching to the middle class and civil and non-governmental organizations. Which would be the limits of private property and which would be the attributions of the State and public power without Infringe the basic conditions for the exercise of civil and democratic liberties? This is one of the questions to be resolved in the relations of public power with the private sphere.

Another point is that of freedom of expression and information and of the mass media. It is linked to the previous topic, since they are the supports of the liberal regimes. By tearing down the assumptions of neoliberalism, "21st century socialism" is launched against the set of individual and personal liberties that define modern society. Chavismo is decanted for a type of anti-liberal model, more oriented towards a strong and authoritarian state with a social commitment. There is a time when freedom of expression becomes annoying for such a regime. What is even more controversial is the role of the mass media. Insofar as they serve private interests, get to erect a mediocratic system that replaces, supplants and challenges the other established powers. The mass media can control, set up and take down governments in the media democracies of our time. The case of the return of the PRI and its candidate Enrique Peña Nieto in Mexico in the 2012 elections, is a clear example of the weight that television stations acquire to impose national policies and the figures of their preference. The monopolistic and hegemonic purpose of the "Televisa" consortium on Mexican society and politics they are manifested since before the presidential elections of 2006 and arrive to the sucession of 2012. The return to the presidency of the PRI republic goes hand in hand with the growing incidence of the mass media on Mexican political life (Villamil, 2010: pp. 13-14). As they are a form of private and corporate power, they contradict public power and become an important counterweight to it, seeking to replace and exceed it. The mass media are born 
into history at the hands of bourgeois society. Along with advertising of brands and commercial products, are sold, communicated and transmitted, information, content and knowledge. This is how "public opinion" is formed, a type of expression of individuals that becomes social opinion before the State, the government and the formal powers. Freedom of opinion and expression are important to counteract abuse and outrages of power (Habermas, 1986: pp. 166-168). By being decreased civil society is more vulnerable to a power that is magnified, without brakes and without counterweights. Although private communication companies must be regulated by the public interest, the State must be prevented from stifling all independent and dissenting opinions. By allowing it, the point of view of intellectuals, academics, journalists and authorized voices that hold a distant or critical opinion regarding the exercise of public power is nullified.

The question of perpetual power is another of the issues that have been tensing the democratic problem in the area. In an area with deep roots of caciquismo, caudillismo and militarism, it is easy for trends to resurface that point towards an extension and prolongation of the popular and constitutional mandate. It must be remembered that the conservative monarchical experiment did not bear fruit, leaving a legal referent and republican constitutional, in a cultural background of exaltation of men and strong figures of power. In post-revolutionary societies and states, the legitimacy of power is justified with the origins and foundations of the revolutionary act, so that the rotation, succession, and transmission of powers is resolved for several successive generations. In this regard, the Cuban case is a damaging referent, while authoritarian post-revolutionary regimes such as the Mexican one solved it with a policy of succession and institutional continuity, a democratic simulation accompanied by a rejection of reelection or with bounded reelectionism. Chavismo moves the parameters in this item, since it intended that the leader would be reelected indefinitely and exports such a scheme towards the nations that claim to follow the "Bolivarian" experiment. It is this aspect of reelection politics, one of the weakest and most controversial of the Chavista process and now Madurista. This point has been used as a pretext by business and military groups to burst the constitutional government of Honduras that had become an allied administration of its Venezuelan counterpart. The legislative, judicial power and the armed forces confronted the Manuel Zelaya government, accusing it of trying to lead the country down the path of Chavismo by attempting to unleash a constituent process to weaken the formal powers. History guards a similarity to Paraguay, in a game of institutional powers, which finishes in the departure of another president-elect. A repressive incident, of police confrontation with a group of peasants who had taken some land, serves as an excuse for the Chamber of Deputies to initiate a political trial and dismiss Fernando Lugo. The battle for institutions expresses an underground and complex dispute over the destiny of nations in Latin America.

3) Political antagonism, democracies under siege 
The Chavista model of socialism of the 21st century leaves a bad impression due to the high dose of authoritarianism and militarism with which it is applied. It is a process without independent social actors and has been replaced with a growing politicization of the military that they have become one of the central agents of Latin American politics. It does not stop being illustrative that the recovery and irruption of democratic processes in the subcontinent has been presented as a rejection to military dictatorships and to the excessive presence of the armed forces in the region. The return of militarism in the subcontinent goes hand in hand with the rebirth of the anti-liberal and anti-globalizer left in the latter part of the 20th century. With a nationalist and neo-populist discourse, the army is installed at the center of Venezuelan political life, supplanting actors and autonomous social subjects that result more complex and unpredictable. Through the military, the political process is under control, in a warlike relationship, of force, which predominates over democratic uncertainty. So far this century, the threats of military coups and of the annulment of democratic and civil life had been moved away. It is settles more and more the idea that military regimes are of exception and that they must respect, hand over, and return power to legitimate authorities. In a nutshell, a constituent military system should not been established (Rouquié, 1984: pp. 384-386). What happened in Venezuela was considered as something accidental, that it would not be reproduced in other places. The paradoxical is that in Honduras returns conservative coupism in 2009, wielding a series of arguments that claim to limit the expansion of the Chavista regime, incubated in turn by left-wing militarism. Threats to democratic regimes increase as armed and war policy demands a greater presence in regional affairs. The political processes of Venezuela and Honduras are two decisive moments in the turns that Latin American authoritarian politics have taken, promoted and impulsed by left and right militarism.

In Venezuela, the state of polarization has led to the partition of the nation. Since the attempt to break the legal order in April 2002, the clash has continued to manifest itself with two antagonistic blocks, confronted, united only by the survival of common formal institutions, a catastrophic coexistence and the fear of an even more chaotic state. In other moments of the "Cold War", ideological and political divisions led to the configuration of two countries separated by the wall as in Berlin and Germany, or as Korea and Vietnam, before national reunification. The worst things about today's democracy are said, but nobody reaches to shake off it as a universal referent. Any political force that moves beyond democratic electoral legitimacy faces international disqualification from a world community that tends to elevate democracy as a point of confluence in the political struggle and by power, in the manner in which it is governs and in the way how command is preserved. What points in the area are political regimes, with hardened democracies, with a rough game, loaded with antagonism and polarization, that pulverize the truth, dilute social reality itself, leading to the establishment of parallel political universes and to equidistant bubbles, in a context of 
unsolvable conflicts. In the theories of political transition, the presence of soft and hard-line groups in the ruling bloc has been studied which could influence the structuring and orientation of public power (Przeworski, 1994: p. 89). The state of internal national tension can last up to 20 years, as in the Venezuelan case. Each one generates their social and political reality, without unreaching to break completely with the other. There is a rupture before the adversary, now enemy and it is disputed him hand by hand, the power, institutions, symbols, streets, public and private spaces, human resources, and territory. A problematic, highly conflictive space is shared, which expresses the struggle and the fight on all fronts.

A highly warlike policy, close to war and the bursting of physical and armed hostilities, maintains a catastrophic balance. From that remote 1992, an exhausted Venezuela has been reached in a conflict that cannot find its way out. The Barack Obama administration (2009-2017) in the USA tried to lighten diplomatic and political relations with Cuba and Venezuela. There has never manifested such a strong rapprochement between the "Cuba Castrista" and the USA, as in the Obama administration with the mediation of Pope Francis. The rise to power of the ultra-conservative Donald Trump in 2017, restores discord before the Cuban regime and the northern empire launches an offensive to remove to Nicolas Maduro from the government, he had barely been re-elected in controversial elections held the same year. Starting from legal interstices and technical moves, both parties engage in a legal, political, and constitutional dispute, which leads to the self-proclamation of Juan Guaido as president "in charge" of Venezuela before the National Assembly in 2019, with the support of the United States, and its allies. Nicolas Maduro, meanwhile, says that he has won the constitutional elections, thereby reaching a point where the international community is pronounced itself by one or the other of the disputed presidents. The international community of nations pretends to influence the political outcome in Venezuela, while the political, military factor, the street presence and the dispute in the population, allow the Maduro government to remain with difficulties.

The factor of relations of force, of warfare, of the military as a tool of last resort, gets involved in the resolution of Latin American conflicts. In Nicaragua it is presented another state of constant tension, started in April 2018, with protests and street confrontations against social security reform. The conflict lasts for the following months, and for now the affirmation of the authoritarian regime of Daniel Ortega Saavedra, the last survivor of the Sandinista governments, is reached. In Nicaragua, conditions point to the establishment of a one-party regime, with the cancellation of opposition forces. In Nicaragua, conditions point to the establishment of a one-party regime, with the annulment of opposition forces. Chavismo comes from the attempt at a military coupist in 1992, a military leader elected in the democratic contest of 1998 and from an increasing activity of the armed forces in national life and in the Bolivarian process. In Nicaragua, there was a popular revolution in 1979, a momentary eviction of 
the Sandinistas from power in 1990, and a return of the post-revolutionary governments in 2006, supported in the military and with little willingness to make democratic concessions. In Nicaragua, the track is lined up for the establishment of a single party regime, in the old style of the post-revolutionary states of "real socialism". Such has been the importance of the opposition mobilizations that have challenged the authoritarian Sandinista government, starting in 2018. Even clearer than in Venezuela, in Nicaragua, the left of revolutionary and Castro origins is launched to demolition of democracy that hinders them, no longer to undertake social reforms, as it was under the pretext of the origins of the Cuban Revolution, but for the crude and stark exercise of political power.

The electoral and democratic left that was able to gain power at the beginning of the current century, to the extent of isolating the US government at the "IV Summit of the Americas" and bursting the Alca in 2015, as a strategic initiative for free trade in the continent with the American leadership, is progressively weakening. Approximately for a decade and a half it lasts the cycle of hegemony of the Latin American left in the subcontinent with Brazil, Argentina and Venezuela at the head of the process of distancing the government of George Bush Jr. in the context of the US war against international terrorism and the warlike escalations in Afghanistan and Iraq. United States withdraws from the region and most of the subcontinent falls into the hands of progressive leftist governments, as never before in regional history. Some authors speak of a neo-developmental alternative in the years of the rise of the leftist rulers in the region (Calderon \& Castells, 2019: pp. 27-28). In Honduras and Paraguay, leftist governments are removed, within the limits of the legal and institutional game, the adversaries take advantage of mistakes and deficiencies they committed, in addition to the coup-oriented spirit that predominates in sectors of the dominant elites accustomed to commanding regularly. Faced with a left that is playing rough and that is distancing itself from the techniques and practices of democracy, influenced by Cuba and Venezuela, the old coupist right that was previously haven withdrawn, revives itself and responds with equally deplorable methods. Nor to whom to go, in a dangerous game, located in the limits of the institutions, the legality and the republic.

In Brazil, the governments of the PT of "Lula" (2003-2010) and Dilma Rousseff are progressively weakening, in the face of opposition protests, accusations of corruption and an intense fight for political legitimacy. Dilma Rousseff is removed from the presidency in 2016, accused of violations to the law and suspicions of corruption. After an interval, the ultra-conservative government of ex-military Jair Bolsonaro rises to power in 2019, after winning the 2018 constitutional elections. Lula had been sent to prison in 2017 and disqualified from participating in the presidential elections, under corruption charges, thereby ensuring that the Brazilian left was removed away from power for a time. The history in Argentina is different, although with similar results. Cristina Kirchner's Peronist left loses the presidential elections in 2015 and they leave power 
for a four-year period. They finally return to the presidency of Argentina in 2019 with Alberto Fernández, shaping an oscillating political state, of antagonisms and increasing polarization in the region. The left loses strength with the removal of the Ecuadorian government from Lenin Moreno in power as of 2017, before his predecessor Rafael Correa, the electoral defeats in El Salvador and Uruguay in 2019 and finally a decisive moment is marked with the crisis of evismo in Bolivia at the end of the same year. In the cases of Cuba, Venezuela and Nicaragua, the role of the military in the service of revolutionary and post-revolutionary governments has complicated the eviction of the power of left-wing governments. In Cuba the pluralistic game is not even allowed, in Nicaragua they approach the Cuban model and Venezuela experiences a state of struggle and constant and permanent resistance of a part of society against the force of the State. In Brazil, Argentina, Ecuador, Uruguay and El Salvador, oscillations and fluctuations are possible because the democratic institutional and legal game keeps in force and viable, despite the difficulties. The case of Bolivia, marks a point and apart.

4) National States, autonomies and separatism

One of the clearest effects of globalization and regionalization is the crisis of nation-states, with all that it entails. You have to add the fact that Latin America has hardly modified its geographical borders in the last century. The division and demarcation of nations was due in part to the decisions of creole elites and oligarchies to establish their areas and zones of influence. Although there is a cultural, social and community background that explains and endorses the demarcation of current nations in the subcontinent, in various cases they have been borders delimited by war factors, annexations and voluntary accessions. The border limits are not in question, except for some minor territorial conflicts, which could arise. What puts national states in trouble is the break from above and the difficulties in the internal integration of their territorial, geopolitical, state, social and cultural space. It must be remembered that these States are an enlargement and a replica of the European, republican and democratic models that proclaimed the legal and political equality of citizens before the law. This implies an educational, pedagogical and cultural work to instill a feeling of national belonging, with a language, an official mythology, a common history, shared values and customs. In essence, the nation is a shared culture (Gellner, 1998: pp. 19-29). There is another rather coercive ingredient that imposes belonging of a nation on its members. This occurs with its doses of cultural and symbolic violence that relegates and obstructs other options within the nation. Group and collective identities can be reproduced to infinity and in the bankruptcy of the national, this risk is confirmed. Nations in general and Latin American nations in particular contain within them a vastness of local and regional identities that must subordinate themselves and submit to the sense of belonging of nationality.

What is interesting is that the fracture within nations has been given basically with cultural demands particularly indigenous that cast doubt on the frame- 
works of the established nation state. Indigenous cultures claim their own space before Western civilization and within a political form that proclaims the universal equalization of citizens within the borders of nation states. Originally, these nations tend to homogeneity and set out to destroy and integrate the autochthonous and indigenous identities that existed in Latin America. In the second half of the 1990s and at the beginning of the current century, the indigenous political force erupted with different cultural references and opposed to the dominant Creole and mestizo tradition in the region. Traditional Latin American democracies offered an image of integration, inclusion and plurality that were not such. There were consolidated political classes and stabilized political parties that concealed a class and racial domination. The coming to power in Brazil of Lula, a former metallurgical leader and of Evo Morales in Bolivia, modified the exclusive character of the subcontinent's restricted democracies. The power of the vote of majority and subordinate social is makes to felt and changed it the face and tonality to Latin American political regimes. This has been evident in the Bolivian case, since the Evismo rethought the frameworks of the national liberal state. The Latin American left had placed neoliberalism as the enemy to fight. The indigenous community tradition rejects western modernity and more emphatically the liberal program that promotes the right of private property and individualism. Mexican neo-Zapatistas in 1994 had already carried out a peculiar integration of indigenous communitarianism with the rejection to the economic and social policies of the prevailing neoliberalism.

Bolivian evismo arose from the social mobilizations that rocked the nation, with sovereign demands on the management of natural and strategic resources. It opposed the use and exploitation of national resources with private purposes and especially for the benefit of multinational companies. Adopt a view point of national from the perspective of the indigenous community, which endorses a sovereign management of natural resources (Gutiérrez, 2009: pp. 32-34). That opens a fissure and a confrontation with foreign companies, sometimes from nations considered friends. The Evismo rises to power against the background of the dispute over natural resources, such as water and gas, and due to its indigenous social extraction, it soon incorporates into the national dispute the aspects of a civilizing order that the indigenous tendencies had kept latent (Stefanoni \& Do Alto, 2006: pp. 63-64). This leads to a drastic rethinking of the type of national state that is being built. Local and regional demands had been resolved in administrative and political terms within the national states, with formulas ranging from the federalist model to the granting of autonomies. In the Latin American case and in the Bolivian experience in particular, there is a cultural and civilizing claim that modifies the way as the national state has been conceived. In the face of globalization and the rise of identities, the multicultural and multi-ethnic character that underlies so-called homogeneous societies and nations has been accepted more naturally. The Evismo takes things as far as questioning fundamental aspects of the prevailing western model, such as the 
rule of law, private property, liberal democracy, the notion of sovereignty, which generates a response from the most integrated and westernized sectors of the Bolivian society.

The reply that received by the Evismo was immediate. From the richest regions of Bolivia erupted a separatist attitude, from the area known as the "Half Moon", which claims to defend the rule of law and oppose the radical indigenism of the constitutional government. Long ago, these separatist movements had proclaimed a particular regionalism, adducing that the richest regions of Bolivia must move away from the rest of the nation and they are owed special treatment because they are the support of the rest of the country. To the territorial, strategic and sovereign claims of the Indian peoples and nations is opposed a separatist claim in the name of private property, accumulated wealth and the rule of law. The national State is shaken by said autonomist and separatist claims, since it is sustained under the precept that it is part of a community integrated above criteria of class or race, ethnicity or religion, locality or region and when it is demanded special treatments over constitutional postulates, it is torn since within the cooperative framework. Water and gas belong to the Bolivians as a whole, beyond the specific adherence of the inhabitants of the territories where the natural wealth is based. The same should apply to acquired and accumulated wealth, only that separatist considerations are made in this case from a privatized property perspective. It is conceived that the wealth generated belongs to the particular individuals who directly appropriate it and who deserve to obtain a personal and group benefit from it. It is forgotten that both private and social wealth is possible because in the national framework the natural and strategic resources necessary to develop the economy, production and therefore accumulation move freely. At the center of the two perspectives, both autonomists and separatists make their own interests prevail over what is national or which deserves it. In indigenous autonomism there is a greater justification because it is a series of delayed and denied claims, which must be promoted to benefit oppressed and excluded segments of society. Group and collective rights barely manage to restore social and political equity among oppressed and marginalized communities to dominant and hegemonic groups.

The delicate of the issue is when it is crossed the civilizing line denying the other part of society to institute an ethnic and racial State that ends with the foundations of the national model, as a universal political entity and of citizen equity. It only gives rise so that the less justified separatism appeal to a purported defense of the rule of law and Western civilizational frameworks. By asserting its strength and wealth over the majority, weakest and most impoverished parts of Bolivian society, it reproduces on a small scale the structural and social inequalities that are expressed in the world and in Latin American reality. And it is given a naturalization letter. Breaking a nation between the rich and the poorest only reflects the absence of national communion and makes civilized coexistence within and outside the established frameworks difficult. Those who 
own more and have more would not be willing to share wealth and benefits with others and the basic agreements of a nation state that pretends to be universal and equitable are broken. Each group and particular community has its own interests that make the existence of the national state unfeasible. The truth is that evolved Latin American democracies are guaranteeing access to power for previously oppressed and marginalized social groups and by taking over the government they have a different agenda than traditional dominant groups. These latter sectors do not like this and accentuate tendencies towards exclusion in both directions. In turn, emerging social and political groups with increasing social power may misinterpret their progress, undoing the model of nation states. There was a moment in Bolivia when it is ended a democracy badly called agreed and the community trends collide with the other part of the nation (Varnoux, 2005: pp. 101-102). It is positive for Latin American democratic processes to open up to groups and sectors historically devoid of institutional power and strength, because that will give more elasticity and integration capacity to political regimes in the area. The difficulty is that if exclusive cultural and civilizing visions rise to power, they could close democracy and put national states in difficulties, triggering autonomist and separatist tendencies in various directions that complicate the possibility of minimal civilized coexistence agreements in the region.

It is noteworthy that the situation in Bolivia is broken in 2019, not so much because of the fracture or civilizing dispute that underlies national tensions, but because of the political side. The Evo Morales government was able to articulate a national agreement that allowed him to remain in power during 2006-2019, including two re-elections. The complications began when he tried to be reelected beyond the legal frameworks. Evo Morales loses a referendum summoned for a legal reform that would allow him another presidential reelection in 2016. Far from this serving to measure his political strength, he resorts to a legal contraption, to seek that the judicial authorities allow him to appear again in the 2019 presidential elections. Finally, he manages to appear again in an election, which casts doubt on the counting of the votes, which triggers strong post-electoral protests. The margins of evismo are severely narrowed, when the police and the army withdraw their support and force him to resign. Evo Morales resigns from the Bolivia presidency in November of the same year, amid questions about the legality and legitimacy of the electoral process and under accusations of links to drug trafficking. The rise to power in Bolivia of ultra-conservative groups, marks a terrible omen on the future of the region. The indigenous and multicultural agenda will be seriously compromised, in the face of the failure of Bolivian Evismo, exacerbating the problems of the continental left. Politics and democracy put into crisis the dynamics of progress that the regional left had experienced. Stumbles are repeated and it is upset the balance of regional forces.

5) Between reelectionism and militarism

In the Central American zone, social and political polarization and radicaliza- 
tion of the left stopped in the eighties. The delivery of the arms of the guerrilla groups in Guatemala and El Salvador, as well as the electoral defeat of the Sandinistas made that will be premiered democratic regimes with a left with a revolutionary background incorporated into the electoral game. The center and center right governments follow one another throughout the last two decades of the last century. The rise of Chavismo in South America affects in the long run in the modification of the relation of forces relations in the Central American region. The influence of the United States and Mexico counteracted the presence of the radical left in the area and was a natural territory for the expansion of the North American economy and politics. The return of the Sandinistas to power, hand in hand with Chavismo in 2006, alters the impasse in that the Central American political life is found. Even more surprising is going to be the conversion toward the Latin American left of the liberal government of Manuel Zelaya in Honduras. In this nation had settled The American presence in the 19th century in dispute with the British influence (Barahona, 1991: pp. 240-241). The Honduran governments of the end of the last century had been characterized by obstructing the advances of the guerrillas that triumphed in Nicaragua and those that had a strong presence in Guatemala and El Salvador. More serious still was that counter-revolutionary provocations against the initial government of the Sandinista revolution were mounted from Honduran territory. However, the weakening of US policy in the area, the growing influence of Chavismo and the management of Venezuelan oil income, reached such a degree that even a nation considered a natural ally of the United States, is approaching towards the Latin American left, disturbing internal business groups and multinational capital.

Zelaya obtains power through one of the traditional Honduran parties (Liberal Party), with a conventional political program and with approaches to different social and political sectors. By taking the political post, the changing regional situation favors him, as it turns out that the options of the left have taken hold until changing the face of South American politics, shaking Central America. Zelaya feels supported and protected by a new relationship of regional forces to mark a distance before a United States paralyzed by the new course of Latin American politics. Like other governments in the area, there are good relations with the South American bloc and the Chávez and Lula's leaderships. Zelaya changes economic and social orientations without going too deep. He does so cautiously because, unlike the Sandinistas, the Honduran people had not voted for a leftist program, but rather the conversion is taking place from power in the face of prevailing regional circumstances. The difficulties begin when he openly joins the Latin American radical left bloc and he threatens to push a constituent process, as has happened in Venezuela, Ecuador, Bolivia and Nicaragua. This political bloc designed a process of transformations that would erode the traditional institutions of representative democracy in the region, such as the political parties, electoral, judicial, and legislative bodies, for the sake of a reconcentration of power in the new political leaders. 
The rising lefts in the area were made of a new model of access to power and what is done with it. The guideline was given by the Venezuelan regime that approaches the old Cuban scheme only that in different circumstances, which do not allow the Marxist-Leninist or Bolshevik revolutionary model to be accepted without hindrance. There is a concentration of power in the hands of the political leader, who is even considering indefinite reelection. In other words that democratic appearance and coverage are maintained indefinitely. Representative institutions overloaded with economic interests are now eliminated or serve the interests of the political chief, who assumes popular plebiscitary representation. The political and military power subdues private agents, civil society and the market, resizing an ambit of the public space highly concentrated. Individual guarantees are not suspended, electoral processes are not canceled, democracy is not openly renounced, and the development of private property and capital is not impeded. Political and cultural limits are not crossed, which would make the process irreversible and irreparable. In short, the devices opened by Latin American democracies are not closed, but they are saturated with the interests of political leaders. In fact, access to power and the exercise of it by left-wing alternatives came to be taken as a deepening of Latin American democracies. What has been in doubt is whether the administration of power of the left would maintain and continue to deepen the democratic option, or cancel it and close it for the sake of processes that have led elsewhere in popular dictatorships, in totalitarian states. The moderate left in the region observed these processes of the hard bloc cautiously. In part they suited him because it further modified the relationship of regional and global forces for the sake of growing national sovereignty, with increasingly limited democracies. Other segments have expressed their concern that they may radicalize internal and regional processes, causing fractures and political breakdowns, leading to the shipwreck of democratic regimes in the area. Such is the case of Honduras, which culminated in the fall of the government, of Nicaragüa that has a strengthening of authoritarianism and of Bolivia, which would lead to the overthrow of Evo Morales.

That is what has been in question in the last decade. It must be taken into account that the political processes of the constituent left lead to a rearrangement of liberal and conservative forces, which observe how traditional or representative institutions that they considered eternal, sacred or untouchable are attacked or violated. In an advanced democratic regime, it is known that institutions can be modified, changed and transformed, and the games of majorities and minorities make public decisions fluctuate. What is complicated is when borders that threaten the existence of democratic regimes are crossed, with a high concentration of command and authority. This serves as an excuse for conservative and even undemocratic sectors to question the viability of the constituent processes and to call for coups of authority and power to depose the established leaders. The Honduran case is significant in this regard. Groups of businessmen, of the Catholic Church and of the military staged a coup against of an elected and legally constituted President. It is a matter of dispute whether he governed well or 
was altering constitutional limits. In fact, there are no regional or global bodies with the power to evaluate the action of governments. The affairs of the coup d'etat and the legitimacy of the Zelaya government moved in this remote territory. In principle, it was a coup and no national or international force should interrupt or suspend a constitutional government by force and resorting to a particular interpretation of the law. This is established legally and culturally. It is part of the common democratic framework in the region. The other problem is the rules of the minimum democratic functioning that all governments must abide by and that show gaps in what is indicated by the organizations in the area. There would not only be the question of how power is accessed, but how it is governed, if the constitutional parameters are respected and the legal changes are technically adequate. In short, if democratic power is exercised. In this same sense, a delicate matter that contravenes democratic criteria is that of indefinite reelection and the perpetuation in power of constituted authorities. In the Mexican case, both in the times of porfirismo and in the era of priismo, constitutional elections were never stopped, individual liberties were never formally suspended, but the population knew that it was a dictatorship or a democratic simulation. This is what must be avoided in the Latin American case, with eternalized leaders and with the reproduction of authoritarian power structures that serve for control and domination, but prevent the development of democratic citizenship.

It is in the same Honduran where it is perceived a return to military leadership and regional coup experiments. While the processes of the left avoided crossing the threshold of authoritarianism completely, the blows have returned with a less crude version, which does not make them less unjust and dangerous. They take advantage of that doubtful margin that is brewing with the constituent processes and the attempts of unlimited reelectionism to promote a coup policy that claims to preserve the constitutional order and are imposed by force. If Chavismo forges a path of leftist authoritarianism, Honduran coup updated conservative methods to weaken and destroy democracies. As there is an extended condemnation of the military governments, command is passed to a de facto civilian president, elections are called and an attempt is made to "wash" the coup with another electoral process carried out in a state of astonishment and collective amazement by institutionalized violence. A coup dye is also felt in the removal of Evo Morales in Bolivia and the difficult reimplantation of democratic political conditions. All aggravated by the reelectionist encouragement of Evismo, the accusations of electoral fraud and popular protests. Anti-democratic left and right are reversing the democratic processes in the region, for the sake of making that their hard interests prevail over those of the citizenry. Chavismo and its regional replicas rely on militarism to come to power and sustain themselves. Conservative coup deposes the constitutional Honduran government close to Chavismo with supposedly legal arguments and uses force to bring the situation back to normal according to its interests. The greatest risk in either case is that democracy becomes a "front" of an increasingly factual political 
game given by relations of force and power. If democracy hinders both, its defense can only come from civil society that is not caught in such limited and narrow visions. We have to wait if that will be possible.

The left has passed into a defensive situation in the region. The wear and tear of power, accusations of corruption and even connections to drug trafficking, has detracted from their strength and credibility. The arrival of leftist options ended up completing a cycle of Latin American democratic processes. Now the political pendulum oscillates against it. In Honduras and Paraguay they were expelled from power with legal tricks. In Brazil, President Dilma Roussef is dismissed, in a context of strong protests and opposition mobilizations. Roussef leaves the presidency of Brazil after a juridical and legal process, backed by a major rejection by Brazilian society. Former President Lula is jailed and is prevented from participating in the presidential elections. The coming to power of the ultra-conservative Jair Bolsonaro changes the regional political conditions, as the left falls defeated in the most important power in South America. In Argentina, in the 2015 presidential elections, Kirchnerism lost the power during a government period. In Ecuador, in 2017, the winning candidate, Lenin Moreno, who represented a policy of continuity of Rafael Correa's management, moves away from the regional left and contradicts the original mandate. He does the opposite of what Zelaya did in Honduras a decade ago. In Uruguay in 2019, the Broad Front, a central group of the left, loses the elections, after ruling at the beginning of the century. Even in El Salvador, the ruling left had lost the elections in the same year. The isolated victory of the leftist candidate Andrés Manuel López Obrador in Mexico in 2018, operates as an isolated event. Neither the return of Kirchnerism to power in Argentina in 2019, recomposes the regional political map. Democracy has managed to survive the victories and defeats of the left of the subcontinent. It remains to wait for it to stay alive, in the face of the increasingly drastic swings of the Latin American political pendulum.

\section{Conclusion}

In the last two decades of the last century, the democratic imaginary is at the center of the political aspirations of Latin American nations. On the lefts, it substitutes the revolutionary perspective and on the right, it gives guarantees of order and governability in the face of the debacle of the military dictatorships. Political centrism is accommodated the democratic game more easily. At this stage, the democratic project is both an achievement and an unfulfilled promise and a problematic reality. It is consolidated as one of the most important universal references, which serves as a background to settle controversies, process the struggle for power and temper violence and antagonism.

The loss of influence of the United States and the West in general over the area, reduces the validity of political universalisms. Democracy is one of those universal referents, which would be subject to the relativizations and adaptations 
of the case. By trying to get her out of the midst, forms of power and politics, rooted and atavistic emerge that the democratic project sought to weaken and contain, I refer to the democracy. Instead of being defeated, democracy acquires the capacity to face with new political realities. The current democratic cycle extends in its duration and stability, democracy comes to stay in Latin America and is advancing by new directions. The restricted, elitist and Classist democracies that predominated in the region give way to new political actors and subjects, to new identities and realities that are transferred to the field of the political and electoral game. Workers leaders, indigenous and women break into Latin American political life and reach the presidency giving another dimension to regional democracy. The lefts rise with the triumph and modify the geopolitical and ideological map of the area.

Another democratic correlation spreads across the subcontinent. American influence is supplanted by other strands of world power, and Latin America decisively joins a more multilateral political table. This is possible from a more democratized zone, and even so, continues to arise the risks for the cancellation of the democratic political game within and outside the nations. Hand in hand with caudillismo, of militarism and of reelectionism, an authoritarianism and Caesarist left threatens to go beyond the horizons of democratic culture. The right wing, supposedly cautious and defensive, turns to the coup file to cancel democratic processes when they feel that they are being harmed too much. The events in Honduras and Paraguay initially indicated that the threats against the constitutional and democratic processes are still there, insofar as the oligarchies and the powers that be continue to consider that democracy is only an instrument for the realization of their class objectives. And on the other hand, Castroism and Chavismo raise a growing shadow over Latin American democracies, with processes induced towards authoritarian and even totalitarian regimes, as happens in Nicaragüa, Venezuela and Bolivia. Meanwhile, Latin American democracy tries to consolidate itself, dragging the wake of fragility that is so common in the zone and faces the pendular oscillations of a growing political antagonism.

\section{Acknowledgements}

Thanks for the translation of the article to Silvia Aminta Tejeda González, who was supported me in this regard.

\section{Conflicts of Interest}

The author declares no conflicts of interest regarding the publication of this paper.

\section{References}

Ackerman, J. (2006). Democratización: Pasado, presente y futuro. Perfiles Latinoamericanos, 28, 117-157. 
Alves, B. (2004). La historia de Lula. De obrero a presidente. Bogotá: Editorial Oveja Negra.

Ansaldi, W. (2001). La democracia en América Latina, más cerca de la precariedad que de la fortaleza. Sociedad, 19, 23-54.

Barahona, M. (1991). Evolución histórica de la identidad nacional. Tegucigalpa: Editorial Guaymuras.

Beasley-Murray, J. (2010). Poshegemonía. Teoría política y América Latina. Buenos Aires: Paidós.

Blanco, C. (2002). Revolución y desilusión. La Venezuela de Hugo Chávez. Madrid: Los Libros de la Catarata.

Calderon, F., \& Castells, M. (2019). La nueva América Latina. México: Fondo de Cultura Económica.

Domhoff, G. W. (1987). Quién gobierna Estados Unidos (15th ed.). México: Siglo XXI Editores.

Gellner, E. (1998). Nacionalismo. Barcelona: Ediciones Destino.

Guillermoprieto, A. (2000). Las Guerras en Colombia. Santa Fé de Bogotá: Aguilar.

Gutiérrez Aguilar, R. (2009). Los Ritmos del Pachakuti. Levantamiento y movilización en Bolivia (2000-2005). México: Bajo Tierra Ediciones/Sísifo Ediciones/Benemérita Universidad Autónoma de Puebla/Instituto de Ciencias Sociales y Humanidades "Alfonso Vélez Pliego".

Habermas, J (1989). El discurso filosófico de la modernidad. (Doce lecciones) (Edition Spanish). Madrid: Taurus.

Habermas, J. (1986). Historia y crítica de la opinión pública. La transformación estructural de la vida pública (3rd ed.). México: Editorial Gustavo Gili.

Heller, C. (2003). La cuestión cubana en los foros multilaterales. Foro Internacional, 173, 675-692.

Mainwaring, S. (1999). La durabilidad de la democracia en América Latina, 1940-1998. Política y gobierno, 2, 315-363.

Medina, M. (2001). El Elegido Presidente Chávez: Un Nuevo Sistema Político. Bogotá: Ediciones Aurora.

O’Donnell, G., \& Schmitter, P. C. (1994). Transiciones desde un gobierno autoritario/4. Conclusiones tentativas sobre las democracias inciertas. Barcelona: Paidós.

Oppenheimer, A. (1992). La Hora final de Castro. La Historia secreta detrás de la inminente caída del comunismo en Cuba. Buenos Aires: Javier Vergara Editor.

Perez-Stable, M. (1998). La Revolución cubana. Orígenes, desarrollo y legado. Unknown Place: Editorial Colibrí.

Poitevin, R., \& Sequén-Manches, A. (2002). Los desafíos de la democracia en Centroamérica. Guatemala: Facultad Latinoamericana de Ciencias Sociales (Flacso).

Przeworski, A. (1994). Algunos problemas en el estudio de la transición a la democracia. In G. O'Donell, P. C. Schmitter, \& L. Whitehead (Eds.), Transiciones desde un gobierno autoritario, 3. Perspectivas comparadas (pp. 79-104). Barcelona: Paidós.

Rouquié, A. (1984). El Estado militar en América latina. México: Siglo XXI Editores.

Sánchez García, A. (2003). Dictadura o democracia. Venezuela en la encrucijada. Caracas: Editorial Altazor.

Sen, A. (2001). La democracia como valor universal. Istor, Revista de Historia internacional, 
4, 10-28.

Seoané, J., \& Taddei, E. (2001). De Seattle a Porto Alegre. Pasado, presente y futuro del movimiento anti-mundialización neoliberal. In J. Seoane, \& E. Taddei (Eds.), Resistencias mundiales (De Seattle a Porto Alegre) (pp. 105-129). Buenos Aires: Consejo Latinoamericano de Ciencias Sociales (Clacso).

Soler, R. (1986). Idea y cuestión nacional latinoamericanas. De la independencia a la emergencia del imperialismo (2nd ed.). México: Siglo XXI.

Stefanoni, P., \& Do Alto, H. (2006). La Revolución de Evo Morales. De la coca al palacio. Buenos Aires: Capital Intelectual.

Taylor, C. (1996). Fuentes del yo. La construcción de la identidad moderna. Barcelona: Paidós.

Therborn, G. (1980). Dominación del capital y aparición de la democracia. Cuadernos Políticos, 23, 16-44.

Varnoux Garay, M. (2005). Octubre negro boliviano. Ecuador debate, 64, 91-103.

Vilas, C. M. (2005). El legado de una década (2nd ed.). Managua: Lea Grupo Editorial.

Villamil, J. (2010). El sexenio de Televisa. Conjuras del poder mediático. México: Siglo XXI. 